\title{
Integration of Strategic Environmental Assessment and Environmental Social Impact Assessment into Strategic Territorial Planning: Lessons Learned from Two Cases of Tourism Destinations In Protected Areas
}

\author{
Marina Nenkovic-Riznic ${ }^{1 *}$, Vladica Ristic ${ }^{2}$, Sasa Milijic $^{1}$, Marija Maksin ${ }^{1}$ \\ ${ }^{1}$ Institute of Architecture and Urban and Spatial Planning of Serbia, Belgrade, Serbia \\ ${ }^{2}$ Project Studio “Our apartment," Belgrade, Serbia
}

Received: 13 November 2015

Accepted: 18 February 2016

\begin{abstract}
Whereas standard strategic environmental assessment (SEA) methodology aims to assess the impacts of certain activities solely on environmental quality, new tendencies in spatial and environmental planning are directed toward the application of environmental social impact assessment (ESIA). Having a wider scope, ESIA also implies assessing the impacts on quality of life as well as on natural and cultural heritage. Case studies in Serbia are used to explore whether the combined application of SEA and ESIA methodology in strategic territorial planning helps control negative effects of tourism, namely in protected areas (PA). The results/findings of the analysed case studies prove that combined implementation of SEA with ESIA methodology in spatial planning helps to overcome conflicts between tourism development and protection of natural and cultural heritage, and quality of life. Also, the analysed case studies (tourism destinations in PA such as Djerdap National Park and Stara planina Nature Park) show that the application of combined SEA and ESIA contributes to better understanding of the specific problems related to sustainable territorial development, and provides support to the planning options and solutions aimed at addressing these problems in a more ecologically and socially justifiable manner. Findings implicate that SEA and ESIA have proved to be instruments for indirect coordination between spatial and tourism planning for achieving sustainable territorial development of tourism destinations in PA.
\end{abstract}

Keywords: sustainable territorial development, strategic planning, spatial planning, sectoral (tourism) planning, strategic environmental assessment, environmental social impact assessment, tourism destination in protected areas

*e-mail: marina@iaus.ac.rs 


\section{Introduction}

The implementation of a holistic approach and coordination between spatial, sectoral, and environmental planning is crucially important for integrated strategic planning for sustainable territorial development. Tourism destinations - primarily those located in the protected areas of natural and cultural heritage (PA) should be the first to adopt strategic planning and management, with the aim to achieve sustainable territorial development and to protect the attractiveness of the PA, and by this to accomplish competitiveness as well.

It is necessary to develop and use instruments that will have a controlling role in the realization of sustainable territorial development and coordination of strategic planning [1]. Is SEA the most efficient instrument for controlling the environmental, social, and economic effects of planned territorial development? Does SEA contribute to the coordination of strategic planning to reach sustainable territorial development of ecologically vulnerable tourism destinations, in particular those in the PA?

Whereas standard SEA methodology aims to assess the impacts of certain activities solely on environmental quality, new tendencies in spatial and environmental planning are directed toward the application of environmental social impact assessment(ESIA). This paper indicates the differences between ESIA methodologies on the one hand, and standard SEA methodology prescribed by EU directives on the other. While SEA is conceived only as an instrument for accomplishing environmental protection objectives, the protection of the quality of life and human health is increasing in importance, as well as the determination of effects that socio-economic activities can have on the investigated area. Since tourism development activities have significant recorded effects on the socio-economic development of tourism destinations, the assessment cannot be reduced only to the analysis and evaluation of negative and positive environmental effects of these activities. For this reason, the existing methodology for undertaking strategic environmental assessment necessitates improvement by including socioeconomic parameters and goals that are recognized as ESIA goals.

The aim of this paper is to contribute to increasing knowledge of the above issues by means of SEA/ESIA for strategic territorial planning of tourism destinations. Different planning and institutional contexts, according to Lemos, Fischer, and Souza, can be challenging for evaluating SEA practices in tourism planning in developing countries [1]. This paper focuses on the SEA/ ESIA controlling role in spatial planning for sustainable territorial development of tourism destinations.

Case studies in Serbia are used to explore whether the application of SEA/ESIA in strategic territorial planning helps control, minimize, or avoid negative effects of tourism, and to check the efficiency of SEA/ESIA as instruments for coordination between spatial and tourism planning for achieving sustainable territorial development of tourism destinations, in particular in PA.

\section{Matherials and Methods}

\author{
The Role of SEA and ESIA in Strategic Planning \\ for Sustainable Territorial Development
}

Strategic planning is one of the instruments for achieving sustainable development, in particular the spatial planning that can offer an integral view of future territorial development. The assumed capacity of spatial planning is based on its spatial dimension and potential to coordinate and integrate various sectoral policies, from economic development, tourism, and transport to environmental protection and other policies. The basic task of spatial planning is to plan sustainable territorial development as a general strategic framework for general and sector policies. Therefore, spatial planning has a controlling function as well, because it enables decision-makers to view the results and effectiveness of different policies in space, as well as to anticipate their efficiency and necessary future adjustments [2, 3]. Strategic environmental assessment is envisaged to diminish or neutralize adverse effects of spatial and sectoral planning on the environment, and to have a coordinating role regarding planning decisions, with a view to achieving sustainable territorial development. This should be applied to tourism destinations as well, since "tourism is an element in spatial plans and the extent of its coverage will frequently depend upon its significance and impact on the local economy" [1].

Many different concepts and tools for comprehensive sustainability assessment of tourism and tourism destinations have been developed. In order to achieve sustainable development of tourism at a destination level, these concepts and tools need to be combined and integrated, as they cover different areas and contribute to different aspects of achieving sustainable development at destinations $[4,5]$. Schianetz et al. argue there is a need for a comprehensive assessment of possible impacts of planned development on the environment and community in order to avoid trade-offs and transferences of problems from one area to another [5]. According to Lemos et al. [1], there is no such thing as a predefined, generic set of criteria suitable for reviewing SEA practices in tourism planning.

The outcome of comparative evaluation of assessment tools and concepts for sustainability implementation [5] is that SEA, as well as most site-specific assessment tools, has difficulties when dealing with cumulative impacts (e.g., increased tourist capacities, which directly increases water consumption, generated municipal solid waste, air pollution, etc.). The evaluation of negative cumulative tourism effects on territorial development is of particular importance in ecologically vulnerable areas such as PA, and in socially and economically depressed areas that contain resources for tourism development.

The application of SEA in tourism planning does not follow any established procedures or methodologies, nor are there specific legal provisions to regulate it. This contributes to assessments often being more sociological- 
ly oriented and concerned with the quality of life/tourist stay rather than the quality of air, soil, etc.

While standard SEA methodology evaluates only the effects of certain activities on environmental quality, ESIA has a wider scope. It takes into consideration the evaluation of all potential positive and negative impacts of activities on physical, geographical, biological, and socioeconomic characteristics of space. The scope of ESIA is also extended by the evaluation of the aforementioned effects on the quality of life of local residents [6], as well as on the protection of natural and cultural heritage.

Considering that tourism destinations and the areas predominantly planned for tourism purposes have to be perceived differently from areas predominantly planned for other purposes (infrastructure corridors, mineral raw material exploitation areas, etc.), ESIA practice is increasingly growing in the current planning practice as a tool for evaluating development alternatives and proposing measures for monitoring in such areas.

SEA is a relatively new tool in the planning process, both in Serbia and across the European Union [7, 8]. The EU Directive on Strategic Environmental Assessment (Directive 2001/42/EC of the European Parliament and of the Council of $27^{\text {th }}$ June 2001 on the assessment of the effects of certain plans and programmes on the environment [9]) and the Protocol on SEA constitute the European legal basis for the implementation of sustainable development planning ideas. The above documents have served as the basis for drafting the Law on SEA (2004) in Serbia [10], which prescribes the application of SEA on development plans and programmes, including those related to the tourism sector, for the purposes of avoiding or limiting the negative effects of planning decisions on the environment.

The challenge is that the legal basis (laws on planning and construction, environmental protection, transport, tourism, etc.) do not establish the obligation to coordinate sectoral planning with environmental and spatial planning. The Law on Tourism (2009) [11] does not mention integral planning or coordination with spatial and environmental planning, nor the obligation of carrying out SEA for sectoral plans. Quite the opposite, sectoral plans (such as the tourism development strategy of the Republic of Serbia, strategic master plans, tourism development programs, etc.) are envisaged as a starting basis for spatial and urban planning. This brief analysis of the legal basis in Serbia reveals that the current legal basis does not provide support for the coordination and integration of strategic planning for sustainable territorial development of tourism in Serbia [12].

Spatial planning in Serbia (national spatial plan, regional spatial plan, spatial plan for special-purpose area, municipality spatial plan, and urban planning) establishes the main planning basis for sustainable territorial development [12]. The Spatial Plan of the Republic of Serbia (SPRS, 1996) [13] is the first strategic document to establish the concept of sustainable development for the whole territory and primary tourism destinations in Serbia (Fig. 1).
With regard to tourism sector planning, only the tourism development strategy of the Republic of Serbia (2006) has been linked to spatial planning (e.g., to SPRS). Over the past several years, 16 strategies and master plans for tourism destinations have been developed. It can generally be stated that the traditional market-driven approach is predominant in these strategies and master plans, without the analysis of planned tourism development impacts on the surroundings and the assessment of environmental, spatial, social, and cultural effects of these impacts. This is in contrast to guidelines of the World Tourism Organization [14]. Due to the market-driven approach, substantial negative effects of tourism on natural heritage, natural resources, and the environment, as well as on local community development, may occur in the realization of certain master plans, especially when it comes to tourism destinations in PA (e.g., Stara Planina and Kopaonik). The main reason for this lies in the fact that tourism planning is an inter-sectoral issue [1].

The problem of coordinating sector planning with spatial and environmental planning is most visible in the tourism sector in the current strategic planning practice in Serbia. After the adoption of tourism development master plans for certain primary tourism destinations in Serbia, a significant problem occurred in developing spatial plans for special-purpose areas and regional spatial plans. The collision between economic sector interests in tourism sector planning and sustainable development of tourism destinations in spatial planning has increased due to the legal obligation to incorporate the planning concepts and solutions of sector plans directly into spatial plans. Without previous verification and without achieving spatial, environmental, social, and economic sustainability, concepts and solutions based exclusively on the sector (economic) approach might jeopardize the planning concepts and solutions based on the holistic approach.

The integration of SEA into spatial and urban planning in Serbia has produced good results in evaluating different territorial development options and - so far - contributing to the improvement of the quality of life and environment. Non-implementation of legal requirements pertaining to the development of SEA for sector plans in tourism represents a limitation in coordinating and integrating the role of strategic environmental assessments in the Serbian planning system.

Under such conditions, the implementation of SEA, with the extended methodology of ESIA, in spatial plans for tourism destinations and binding regulation plans for tourist resorts (the plan of general regulation and the plan of detailed regulation) is the only control instrument enabling the indirect coordination between sector-oriented strategic master plans and spatial and environmental planning.

Problems and possibilities of establishing the coordination of strategic planning for sustainable territorial development of tourism destinations through the application of SEA and ESIA are analyzed on the example of spatial planning and sector planning for two tourism destinations in PA. 


\section{Methodology for SEA with ESIA Application}

Various development activities have both positive and negative implications for environmental quality, quality of life, and economic development of local communities and regional surroundings. For this reason, the evaluation of these activities must include all impactful dimensions of sustainable development: environmental, social, and economic. Compared to the standard approach to the evaluation of effects of these activities on the environment

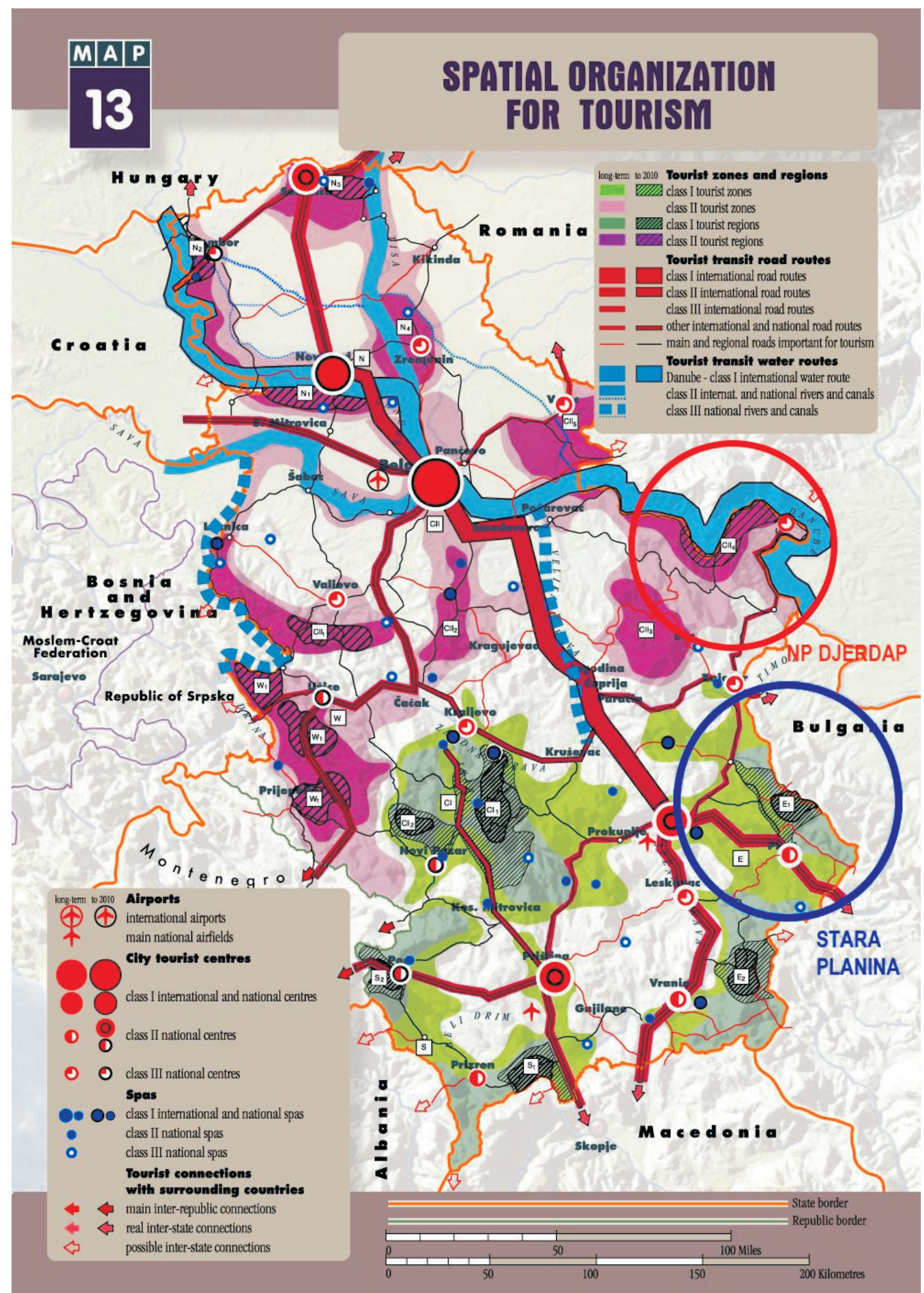

Fig. 1. Primary tourism destinations in Serbia.

Source: Milijic et al. Institute of Architecture and Urban and Spatial Planning of Serbia, Spatial Plan of the Republic of Serbia, Thematic map of tourism destination development, 1996 [13]. 
applied in SEA, as prescribed by EU directives (Directive EC 2001/42/EC on SEA, Directive 2011/92/EU on EIA) and analyzed and improved by many authors [15-17], new tendencies in spatial and environmental planning for sustainable territorial development are directed toward ESIA.

In the ESIA procedure applied to tourism, it is crucial to identify and evaluate direct, indirect, and cumulative effects arising from tourism-related and other activities. These activities are compared with the so-called null alternative (meaning to say that these activities will not be carried out) in order to quantitatively and qualitatively determine their effects. Based on the evaluation of the effects of almost all activities, the final conclusions of ESIA provide insight into direct and indirect effects of planned activities, and enable the formation of a set of measures for offsetting or diminishing adverse effects.

ESIA should necessarily take into account both the existing state of environmental quality (water, air, land, noise, ionizing, and non-ionizing radiation) and the quality of life (the percentage of the local population and tourists
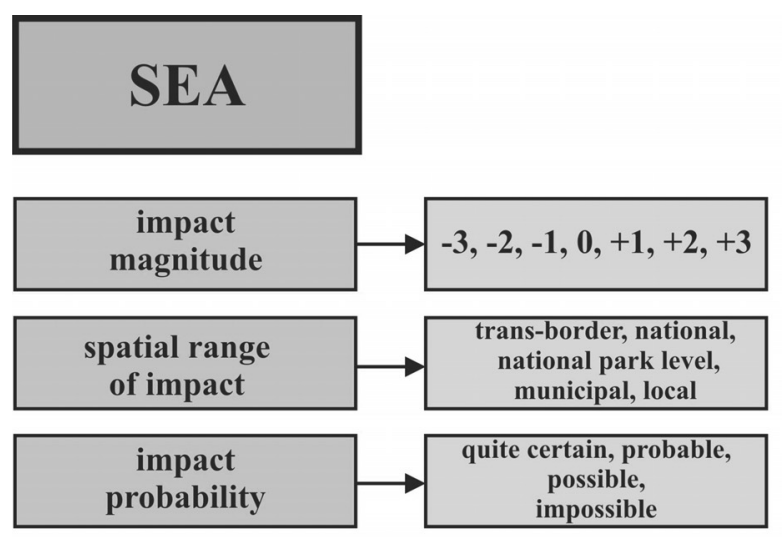

exposed to the increased pollution of air, water, land, and noise, and then the percentage of the local population and tourists who consider the conditions in the environment to be satisfactory/adequate, as well as the quality of jobs in tourism and those generated by tourism, the quality and availability of public and tourism infrastructure and services, etc.). It should also take into consideration the status and condition of the protected natural and cultural heritage, including the data on the manner and intensity of the use of space for tourist facilities, infrastructure, and activities (characteristics of tourist facilities and infrastructure, number of visitors and intensity of the tourist use of space at monthly and annual levels and during peak season, etc.). Also, tourism development in PA can be a major economic justification for their protection, but it can pose a great risk [1]. By taking into account socio-economic parameters as well, ESIA should give a comprehensive idea about the consequences that development activities may have for a certain area.

Compared to the standard instruments in SEA, ESIA introduces new parameters for quantitative and qualitative
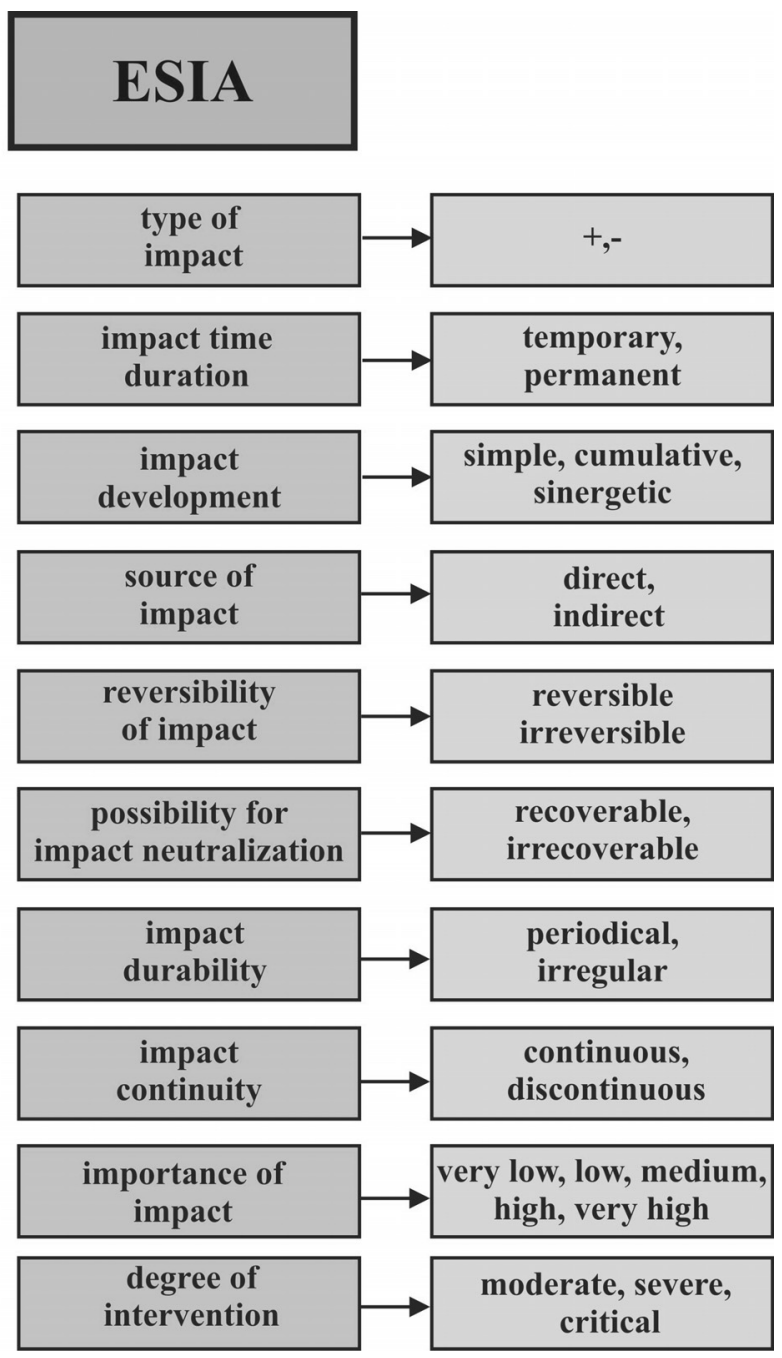

Fig. 2. Differences between evaluation parameters in SEA and ESIA. Source: Authors 
assessment of the effects of planned development activities in order to improve the existing methodological framework (Fig. 2).

SEA has been conducted in the Republic of Serbia over the past 10 years based on theoretical research by Fischer [6, 7] and Therivel [18]. They provide estimations of environmental impacts of spatial and urban planning solutions, and there is a tendency to expand their application to sector plans and strategies (in accordance with EU directives). Although the legal basis for the implementation of SEA in Serbia has been innovated several times since 2004, SEA methodology still remains vaguely defined. This has encouraged a more comprehensive research work on developing the specific and widely applicable methodology for carrying out SEA $[6,19-21]$. None of the researched methodologies have been adopted as an official and binding methodology in Serbia. This has resulted in an uneven quality of SEA, but it has also provided a greater flexibility in its application, in accordance with specific problems and concepts of plans and projects to which it is applied. A common feature of these methodologies is that they have been mainly based on the determination of a set of goals of SEA, i.e., they have primarily had an environmental character.

The existing methodology of SEA for impacts of tourism-related activities has been improved in the Institute of Architecture and Urban and Spatial Planning of Serbia (IAUS) through several research projects in order to define a uniform methodology for SEA application in the elaboration of spatial and regulation plans. Although ESIA has not been recognized on a legal basis and in strategic documents in Serbia, it has been implemented by IAUS indirectly through the combined application with SEA in the elaboration of spatial plans for tourism destinations and binding regulation plans for tourist resorts in Serbia.

It has significantly improved the impact evaluation of tourism-related and other activities by introducing the socio-economic dimension as equally important in the evaluation process. Therefore, previously defined goals of SEA, which concerned environmental quality parameters, issues of biodiversity, geo-diversity, and landscape have been extended with goals of ESIA to include cultural and historical heritage, population and human health, socio-economic development of local communities, development and availability of public infrastructure and services, as well as strengthening of institutional competence in environmental protection.

Fields and objectives of combined SEA and ESIA methodologies are given in Table 1.

Based on the abovementioned goals, ESIA indicators have been established: e.g., the percentage of population/ tourists with adequate collection systems and wastewater treatment, the percentage of population/tourists with access to basic health care, the number of tourists under the influence of noise, the percentage of population/tourists exposed to increased air pollution derived by tourist areas, the number of development programs for environmetal protection in tourism destination/PA, the number of
Table 1. The fields and objectives of the SEA and ESIA.

\begin{tabular}{|c|c|}
\hline Field & Objectives \\
\hline SEA & SEA \\
\hline $\begin{array}{l}\text { 1. Natural } \\
\text { areas }\end{array}$ & $\begin{array}{l}\text { 1.1. Protection of the landscape } \\
\text { 1.2. Protection of natural areas } \\
\text { (geomorphological, hydrographic and } \\
\text { geological) } \\
\text { 1.3. Preserving biodiversity (flora and fauna) }\end{array}$ \\
\hline $\begin{array}{l}\text { 2. Natural } \\
\text { resources }\end{array}$ & $\begin{array}{l}\text { 2.1. Rational use of non-renewable and } \\
\text { greater use of renewable energy resources in } \\
\text { tourist areas } \\
\text { 2.2. Increase in energy efficiency } \\
\text { 2.3. The introduction of cleaner technologies }\end{array}$ \\
\hline 3. Air & $\begin{array}{l}\text { 3.1. Reducing the levels of air pollution } \\
\text { from vessels and in the transport corridors } \\
\text { (increased from the raised capacity) }\end{array}$ \\
\hline $\begin{array}{l}\text { 4. Water and } \\
\text { land }\end{array}$ & $\begin{array}{l}\text { 4.1. Development of sewerage infrastructure } \\
\text { and facilities for the treatment of waste water } \\
\text { 4.2. Reduction of erosion and revitalization of } \\
\text { eroded areas }\end{array}$ \\
\hline 5. Waste & $\begin{array}{l}\text { 5.1. Improvement and utilization of waste, its } \\
\text { treatment and disposal in tourist areas }\end{array}$ \\
\hline ESIA & ESIA \\
\hline $\begin{array}{l}\text { 6. Cultural } \\
\text { heritage }\end{array}$ & $\begin{array}{l}\text { 6.1. The protection of cultural heritage, } \\
\text { preservation of historical buildings and } \\
\text { archaeological sites }\end{array}$ \\
\hline $\begin{array}{l}7 . \\
\text { Population } \\
\text { and health }\end{array}$ & $\begin{array}{l}\text { 7.1. Defining a water supply system that will } \\
\text { allow access to the physically, chemically and } \\
\text { biologically clean drinking water for local } \\
\text { residents and tourists } \\
\text { 7.2. Accessibility of sewerage infrastructure } \\
\text { and evacuation of waste for local population } \\
\text { and tourist facilities } \\
\text { 7.3. Protecting and monitoring the health of } \\
\text { local residents and tourists } \\
\text { 7.4. Creating the conditions for leasure and } \\
\text { recreation }\end{array}$ \\
\hline $\begin{array}{l}\text { 8. Economic } \\
\text { and } \\
\text { institutional } \\
\text { development }\end{array}$ & $\begin{array}{l}\text { 8.1. Stimulating economic development } \\
\text { through tourism and local employment } \\
\text { 8.2. Improving the service for environmental } \\
\text { protection and its monitoring and control }\end{array}$ \\
\hline
\end{tabular}

Source: Authors

measurment points in the monitoring systems, the amount of environmental information in the media, etc.

The "initial methodology" or "methodology for SEA application" has implied determining planning solutions, i.e., activities, which could have significant negative or positive environmental effects, or relatively great territorial scope. The impacts have been quantified by means of numerical indicators ranging from -3 to +3 (including " 0 " to denote that a certain activity does not have any effect on environmental quality parameters), while their territorial coverage has been expressed as trans-border, national, regional, municipal, or local (in case a certain tourism destination has some special purpose it has been marked as a national park, nature park, 
Table 2. SEA criteria for impact strength.

\begin{tabular}{|c|c|}
\hline Size and description of impact strength & Mark \\
\hline $\begin{array}{c}\text { Critical } \\
\text { Strong negative impact }\end{array}$ & -3 \\
\hline $\begin{array}{c}\text { Higher } \\
\text { Higher negative impact }\end{array}$ & -2 \\
\hline $\begin{array}{c}\text { Lower } \\
\text { Lower negative impact }\end{array}$ & -1 \\
\hline $\begin{array}{c}\text { No impact or impact unknown } \\
\text { data or not applicable }\end{array}$ & 0 \\
\hline $\begin{array}{c}\text { Positive } \\
\text { Lower positive impact }\end{array}$ & +1 \\
\hline $\begin{array}{c}\text { Favorable } \\
\text { Higher positive impact }\end{array}$ & +2 \\
\hline $\begin{array}{c}\text { Very favorable } \\
\text { Strong positive impact }\end{array}$ & +3 \\
\hline
\end{tabular}

Source: Authors

Table 3. SEA criteria for territorial distribution of impacts.

\begin{tabular}{|c|c|}
\hline Territorial distribution of impact & Label \\
\hline Trans-boundary & $\mathrm{TB}$ \\
\hline National & $\mathrm{N}$ \\
\hline Regional & $\mathrm{R}$ \\
\hline Municipal & $\mathrm{M}$ \\
\hline $\begin{array}{c}\text { Local } \\
\text { (The possible impact on a zone or } \\
\text { part of the municipality) }\end{array}$ & $\mathrm{L}$ \\
\hline
\end{tabular}

Source: Authors

Table 4. SEA criteria for occurrence probability of impacts.

\begin{tabular}{|c|c|}
\hline $\begin{array}{c}\text { Occurence probability } \\
\text { Description }\end{array}$ & Label \\
\hline $\begin{array}{c}100 \% \\
\text { Certain impact }\end{array}$ & $\mathrm{C}$ \\
\hline $\begin{array}{c}\text { over } 50 \% \\
\text { Possible impact }\end{array}$ & $\mathrm{I}$ \\
\hline $\begin{array}{c}\text { less than } 50 \% \\
\text { Potential impact }\end{array}$ & $\mathrm{P}$ \\
\hline $\begin{array}{c}\text { less than } 1 \% \\
\text { Impact not possible }\end{array}$ & $\mathrm{N}$ \\
\hline
\end{tabular}

Source: Authors

etc.). This has partially enabled the evaluation of tourismrelated and other activities' impacts on the quality of air, water, and land (previously defined goals of strategic environmental assessment). However, the issues of socioeconomic development and effects of the activities on the quality of life and local communities have not been seriously considered.
Table 4. SEA criteria for occurrence probability of impacts.

\begin{tabular}{|c|c|}
\hline $\begin{array}{c}\text { Occurence probability } \\
\text { Description }\end{array}$ & Label \\
\hline $\begin{array}{c}100 \% \\
\text { Certain impact }\end{array}$ & $\mathrm{C}$ \\
\hline $\begin{array}{c}\text { over } 50 \% \\
\text { Possible impact }\end{array}$ & $\mathrm{I}$ \\
\hline $\begin{array}{c}\text { less than } 50 \% \\
\text { Potential impact }\end{array}$ & $\mathrm{P}$ \\
\hline $\begin{array}{c}\text { less than } 1 \% \\
\text { Impact not possible }\end{array}$ & $\mathrm{N}$ \\
\hline
\end{tabular}

Source: Authors

Based on the quantitative and qualitative assessment, a table matrix with defined impact strength, territorial distribution, and occurrence probability (Tables 2, 3, and 4) has been made. Evaluation results expressed through the matrix have enabled determination of measures for neutralizing and diminishing the effects of tourism-related activities on environmental quality parameters.

The criteria for evaluating the intensity and spatial dimension of the impact of the planning solutions on the SEA objectives served as a basis for evaluating the importance of the identified impacts in achieving these objectives (Table 5). The impacts of strategic significance for the tourism destination were those with strong (positive or negative) effect at a trans-boundary or regional level.

The major problem that appeared in the elaboration of spatial plans for tourism destinations in PA in Serbia (nature parks, national parks, cultural heritage in the UNESCO World Heritage List, etc.) was caused by the failure of SEA to provide precise quantitative and qualitative determination of cumulative and synergistic effects of planned activities, determination of reversibility, durability, and continuity of impacts, and thereby their neutralization. Besides, the applied methodology placed a significant emphasis on determining the effects of the activities on the environment and, in accordance with this, only prescribed the measures for neutralizing the effects on the quality of water, air, noise, ionizing and nonionizing radiation, etc.

Due to the mentioned problems, in 2006 the IAUS started to implement the adapted SOTAVENTO methodology [22], an innovative, adjusted, and improved research instrument that enabled the application of ESIA for the purposes of evaluating the effects of planned activities on territorial development of tourism destinations. The mentioned methodology (hereinafter referred to as "ESIA methodology") has taken the basic systematization of impacts (type, duration, development, sources, reversibility, possibility of neutralization, durability, continuity, importance, and degree of necessary intervention) from SOTAVENTO methodology (Table 6).

However, ESIA methodology cannot be used as the one and only methodology in impact assessment, either, considering that more detailed evaluation of 
Table 5. Model for evaluating the impact for planning solutions using the SEA method.

\begin{tabular}{|c|c|c|c|}
\hline \multirow{2}{*}{$\begin{array}{l}\text { Planning } \\
\text { solution }\end{array}$} & \multicolumn{2}{|c|}{ Identification and evaluation of significant impacts } & \multirow[b]{2}{*}{ Explanation } \\
\hline & $\begin{array}{c}\text { Number of the SEA } \\
\text { objective being considered }\end{array}$ & Rank & \\
\hline & & $\begin{array}{c}\text { Here (on the basis of Table } 3 \text { ) the combined } \\
\text { impacts of the planning solution are shown, } \\
\text { in order to better observe the intensity, spatial } \\
\text { dimension, probability, and frequency of the } \\
\text { impacts, } \\
\text { e.g., C-2PL, C+3LkLt }\end{array}$ & $\begin{array}{l}\text { An explanation is given here } \\
\text { regarding the impact of the planning } \\
\text { solution, e.g., the planning solution } \\
\text { can generate "quite sure" negative } \\
\text { long-term impacts at a regional level } \\
\text { for a particular SEA objective. }\end{array}$ \\
\hline
\end{tabular}

Source: Authors

Table 6. Model of the evaluation matrix for the impacts of potential conflicts of the planning solutions using the ESIA method.

\begin{tabular}{|c|c|c|c|}
\hline \multirow{2}{*}{$\begin{array}{l}\text { Number } \\
\text { of PS }\end{array}$} & \multirow{2}{*}{$\begin{array}{l}\text { Planning solutions (PS) that } \\
\text { could potentially cause conflicts }\end{array}$} & \multicolumn{2}{|r|}{ Identification and evaluation of the significant impacts } \\
\hline & & $\begin{array}{l}\text { Direct } \\
\text { impact }\end{array}$ & Rank of the impact \\
\hline & & & $\begin{array}{c}\text { Tag for the rank of influence: } \\
\text { + prevailing positive impact, } \\
\text { - prevailing negative impact, } \\
\text { TEM - temporary, PEM - long-term, } \\
\text { indirect, } \\
\text { SIM - simple, SIN- synergetic, CUM - cumulative, DIR- direct, IND - } \\
\text { REV- reversible, IRV - irreversible, } \\
\text { REC - neutralization possible, IRC- neutralization impossible, } \\
\text { PER - periodic, IRG - irregular, } \\
\text { CON - continuous, DIS- discontinuous } \\
\text { VERY LOW- very low importance, LOW-low importance. MEDIUM - } \\
\text { medium importance, VERY HIGH - very high importance } \\
\text { The rank of influence is evaluated in a similar way to the SEA } \\
\text { methodology. }\end{array}$ \\
\hline
\end{tabular}

Source: Authors

the effects (particularly with regard to their territorial distribution and impact strength) is carried out by the initial SEA methodology. Table 7 presents a comparison of the two methodologies with their positive and negative characteristics. Comparative analysis is based on the results of more than 40 SEA and ESIA studies conducted in IAUS, and their positive and negative effects, advantages, and disadvantages on planning, which were also used in this research.

This table leads to the general conclusion that there is a strong necessity for combining these two methodologies, especially if we consider the importance of the evaluation of the effects of planned tourism-related activities on the protection of environmental quality, natural and cultural heritage, and sustainable territorial development.

Each of the above-mentioned methodologies has both positive and negative characteristics, which directly indicates the necessity for their complementary and combined implementation.

Only through a direct application of both methods is it possible to obtain a comprehensive assessment of the effects of the planned activities on sustainable territorial development.
Table 7. Comparison of ESIA and SEA methodologies in relation to the degree to which criteria are observed.

\begin{tabular}{|c|c|c|}
\hline $\begin{array}{l}\text { Pos./Neg. } \\
\text { Assessment } \\
\text { of methodology } \\
\text { according to criteria }\end{array}$ & ESIA & SEA \\
\hline Diversified quantitative assessment & - & + \\
\hline $\begin{array}{l}\text { Assessment of simple, cumulative } \\
\text { and synergistic effects }\end{array}$ & + & - \\
\hline Evaluation of variant solutions & - & + \\
\hline $\begin{array}{c}\text { Assessment comprehensiveness } \\
\text { (ecological, economic, } \\
\text { social indicators) }\end{array}$ & + & - \\
\hline Legal grounds & - & + \\
\hline Degree of necessary intervention & + & - \\
\hline Territorial distribution of impact & + & + \\
\hline Possibility for neutralizing the impact & + & - \\
\hline
\end{tabular}

Source: Authors 
Case Studies: Combined Complementary Methodologies for SEA and ESIA Application in Spatial Plans for Djerdap and Stara Planina Tourism Destinations

The role and the results obtained by the combined complementary methods for carrying out SEA/ESIA for tourism destinations will be discussed on the examples of special-purpose area spatial plans for two tourism destinations in PA: Djerdap National Park and Stara Planina Nature Park (which also can be seen in Fig. 1) $[23,24]$.

These cases are taken into consideration because they are two of the most important primary tourism destinations in PA within the territory of Serbia. Djerdap National Park has potentially the most attractive tourism assets on the whole section of the Danube through Serbia, yet it remains an underdeveloped primary tourism destination. Stara Planina Nature Park has exceptional potential tourism development in the mountains of Serbia, but it is yet to be developed as a primary tourism destination. The protection regimes for the natural and immoveable cultural heritage prescribed for the National Park and the Nature Park territory can have great comparative advantages in tourism (taking into account the potential attractiveness of the protected assets, on the one hand), while they directly influence the quality of life of people and socio-economic development of local communities with regard to limitations in carrying out and developing the activities, as well as limitations for the construction of tourist facilities in the PA, on the other hand. Tourism development based on the attractiveness of both PA, as well as potential conflicts between different activities, require more complex consideration of all potential effects on environmental elements, protected heritage, quality of life, and socio-economic development. Therefore, it was necessary to precisely determine the cumulative and synergistic effects of certain planning solutions on the environment and local community, as well as the strength and territorial distribution of these effects, with the aim of reducing the assessed negative impacts and achieving positive effects for the sustainable territorial development of this area, which makes them an interesting field of research.

\section{Djerdap National Park}

Occupying the area of $637 \mathrm{~km}^{2}$, Djerdap National park is situated in the eastern part of the Republic of Serbia, on the very border with the Republic of Romania. It is included in the lists of important plant areas, important bird areas, and prime butterfly areas. In addition, it is included in the Tentative List of UNESCO World Heritage (2011), the list of Carpathian protected areas, as well as in the program of the European Green Belt Project. It is also part of the Emerald Network of Areas of Special Conservation Interests in Serbia. Valuable immoveable cultural heritage of the national park is an important element of its cultural identity. The most attractive is the archaeological site of Lepenski Vir (dating from between 7,000 to 6,000 years $\mathrm{BC}$ ). There are numerous traces and remains of fortification structures dating from the Roman and early Byzantine periods: the remains of the Roman limes on the Danube (Diana Fortress, the road through the Djerdap Gorge with Pontes), and the medieval Golubac and Fetislam fortresses. Besides this, the area has other, equally important purposes - it is a primary tourism destination with year-round offerings; it is a section of Danube international waterway E-80; it has important hydro-energy potential (with two existing hydro-electric power plants on the Danube), rare minerals, etc.

At the same time, this is a peripheral rural area comprising 27 settlements with about 42,000 inhabitants (2002Census), with pronounced depopulation and rural unemployment. But the Djerdap area has experienced unbalanced development: in 2011 the level of development of the municipality varied from $80 \%$ of the republic average to less than $60 \%$. The level of tourism development nowadays is not at its peak, achieved in the 1980s. Therefore, the positive effects of tourism on the socio-economic development of local communities are not sufficient, taking into account its potentials.

An SEA with ESIA study was developed for the needs of elaborating the Spatial Plan for the Special-Purpose Area of Djerdap National Park (hereinafter: SPSPA Djerdap) [23].

\section{Stara Planina Nature Park}

Occupying an area of $1,143 \mathrm{~km}^{2}$, Stara Planina Nature Park is situated in the eastern part of Serbia, on the border between the Republic of Serbia and the Republic of Bulgaria. It has been designated one of the important plant and important bird sites. According to the SPRS, it is regarded as Serbia's primary tourism destination with year-round offerings. It is also an area containing a great number of cultural monuments, as well as authentic old mountain villages, water sources of national and regional importance, etc.

At the same time, this is a peripheral rural area comprising 78 settlements with about 73,700 inhabitants (2002Census), with the depopulation process well underway and serious problems of poverty and an aging rural population. The Stara Planina area has unbalanced development, as in 2011 the level of municipal development varied from above $80 \%$ of the national average to less than $60 \%$. As tourism is still in the initial phase of development, it has no positive effects on the socio-economic development of local communities.

SEA with ESIA was carried out $[25,26]$ for the purposes of the Spatial Plan for the Special-Purpose Area of the Stara Planina Nature Park (or SPSPA Stara Planina). 


\section{Results and Discussion of the Two Cases Analysis}

\section{Results of SEA/ESIA for SPSPA Djerdap}

Through the use of combined SEA and ESIA instruments, the effects of certain planning solutions have been specified according to the type of impact, impact time duration and development, impact source, impact reversibility, and possibility of neutralizing the impact, as well as impact durability, continuity, and importance, and the degree of necessary intervention. The prescribed goals of SEA/ESIA have been expressed through indicators and elaborated upon in more detail through specific goals for each of the fields mentioned in Table 1. Considered indicators were:

- Number of species of wild flora and fauna (size, state of health, population structure, and areas of rare and significant species).

- Number, size, and spatial distribution of landscape types, and types and scope of damage reparation activities and re-cultivation of degraded landscapes.

- Number of days that exceed air pollution limits.

- Types and numbers of registered/used vehicles, the percentage of vehicles older than 6 years.

- Percentage use of electricity, gas, and renewable energy sources.

- Percentage of households connected to water supply and sewerage.

- Percentage of treated sanitary wastewater.

- Percentage of recycled/processed waste.

- Number of protected or identified for protection objects/areas of natural and cultural heritage.

- Percentage of population with adequate collection systems and wastewater treatment.

- Percentage of tourist beds with adequate collection systems and wastewater treatment.

- Percentage of population with access to basic health care.

- Percentage of tourist beds with access to basic health care.

- Number of people and tourists under the influence of noise.

- Health condition and number of species in the woods.

- Number of development programs for environmental protection.
- Number of measurement points in the monitoring systems.

- Amount of environmental information in the media. In the case ofDjerdap, the SEA/ESIA process has shown that the completion and intensification of existing and the construction of new tourist facilities can have a negative impact on local conservation and the improvement of genetic, species, and ecosystem diversity, increase noise and vibration within the built space, but also have a very positive impact within the limits of the PA conservation and presentation (both natural and cultural heritage), sustainable use of natural resources, health protection of the population, and providing conditions for leisure and recreation. These smaller negative impacts could be offset by adequate environmental protection measures.

SEA and ESIA methodologies have enabled a more detailed classification of the environment in the territory of Djerdap National Park, according to the assessed effects of planning solutions on the protection and improvement of environmental quality and socio-economic development. The planning solutions for tourism development (proposed by the master plan for the Lower Danube Tourism Destination [27], and implemented in SPSPA Djerdap) have displayed several potentially negative effects on the environment, and quality of life and socioeconomic development for local communities, which can be controlled by adopting the measures proposed by ESIA (Table 8).

Negative local effects for a long period of time are expected on the PA level. These impacts have a lower intensity level, are discontinuous and reversible, and can be neutralized through natural or anthropogenic intervention.

The necessary public insight implies and enables the participation of the local community, while also facilitating easier acceptance of proposed measures.

\section{Results of SEA/ESIA for SPSPA Stara Planina}

Based on SEA combined with ESIA, tourism development has been evaluated for zones with different protection regimes. The goals of the SEA have also been expressed through indicators, with minor differences form those used for NP Djerdap (mostly in the area of pollution prevention control, since PA Stara Planina has more

Table 8. Evaluation of potentially negative effects of SPSPA Djerdap.

\begin{tabular}{|c|c|c|c|}
\hline \multirow{2}{*}{ Number of PS } & Planning solutions (PS) that could & \multicolumn{2}{|c|}{ Identification and evaluation of the significant impacts } \\
\cline { 3 - 4 } & potentially cause conflicts & $\begin{array}{c}\text { No of SEA and ESIA } \\
\text { objective being considered }\end{array}$ & Rank \\
\hline \multirow{2}{*}{4.1} & Completion and intensification of & 1.1 &,- PEM, SIN, INDIR, REV, REC, IRG, \\
& existing tourist facilities & 1.3 & DIS, LOW \\
\hline \multirow{2}{*}{4.2.} & The construction of new tourist & 1.1 & -, PEM, SIM, IND, REV, REC, IRG, \\
& facilities & 6.1 & DIS, LOW \\
\hline
\end{tabular}

Source: Authors 
Table 9. Evaluation of potentially negative effects on the environment of SPSPA Stara Planina at Jabučko Ravnište-Leskovac Tourist Resort.

\begin{tabular}{|c|c|c|c|}
\hline \multirow{2}{*}{$\begin{array}{l}\text { Number } \\
\text { of PS }\end{array}$} & \multirow{2}{*}{$\begin{array}{l}\text { Planning solutions (PS) that could } \\
\text { potentially cause conflicts }\end{array}$} & \multicolumn{2}{|c|}{ Identification and evaluation of the significant impacts } \\
\hline & & $\begin{array}{c}\text { No of SEA and ESIA } \\
\text { objective being considered }\end{array}$ & Rank \\
\hline \multirow[b]{2}{*}{4.1} & \multirow{2}{*}{$\begin{array}{l}\text { Realization of the tourist accommodation } \\
\text { capacity of Jabucko Ravniste }\end{array}$} & $\begin{array}{l}3.1 \\
4.1 \\
4.2 \\
\end{array}$ & $\begin{array}{c}\text {-, PEM, SIN, INDIR, IRV, REC, PER, } \\
\text { CON, MEDIUM }\end{array}$ \\
\hline & & $\begin{array}{l}7.1 \\
7.2 \\
7.3 \\
7.4\end{array}$ & $\begin{array}{c}\text {-, PEM, CUM, DIR, IRV, REC, } \\
\text { PER,CON, MEDIUM }\end{array}$ \\
\hline
\end{tabular}

Source: Authors

concentrated tourism capacities, and consequently more production of waste and wastewater, etc.).

Based on the results of the assessment, it is concluded that significant positive effects of implementation of the SPSPA Stara Planina will be particularly manifested in:

- The protection and improvement of the natural environment.

- Conservation, presentation and adequate use of natural and cultural heritage.

- Overall economic effects and uniform growth in local employment (in the field of tourism, agriculture and other complementary activities).

- Protection and improvement of health of local population.

- Uniform development of infrastructure and improvement in the quality and accessibility of public and tourism infrastructure and public services.

- Creation of conditions in which tourism and recreation will be accessible to all tourists, etc.

It is concluded that, with the concept of dispersive tourism development and construction that has been implemented in most parts of the area covered by SPSPA Stara Planina (in about $88 \%$ of the area), none of the planning solutions will generate significant long-lasting unfavourable effects on the environment that cannot be kept under control [25].

In the case of Stara Planina, completing and intensifying the use of existing and development of new tourist facilities can have a positive long-term cumulative effect on health and the creation of conditions for leisure and recreation.

However, in addition to the SPSPA Stara Planina, the master plan of the Jabučko Ravnište-Leskovac Tourist Resort [28] has also been elaborated upon, without harmonizing the development of this resort with the development vision and concept of Stara Planina primary tourism destination. This plan has doubled the accommodation capacity in the mountain zone compared to the capacity envisaged by the SPSPA Stara Planina. ESIA indicated (Table 9) that the concept of high construction concentration, which was implemented in the Jabučko Ravnište-Leskovac tourist resort with long-lasting adverse effects on the environment and the quality of life of local residents (due to the uneven distribution of workplaces, planned dominant participation of the employed from further surroundings, etc.), was implemented only in the smaller part of the area covered by the SPSPA Stara Planina (in about $12 \%$ of the area). The mentioned concept is much more difficult to control than the concept of dispersive development, which is more suitable for the protected area of Stara Planina Nature Park.

Implementation of this planning solution for Jabučko Ravnište-Leskovac Tourist Resort, according to multicriteria evaluation, can have a long-term negative synergistic effect on reducing the levels of air pollution from vessels and in the transport corridors, developing sewage infrastructure and facilities for the treatment of wastewater, reducing erosion and revitalization of eroded areas, defining a water supply system that will allow access to potable water for local residents and tourists, accessibility of sewage infrastructure and evacuation of waste for the local population and tourist facilities, protecting and monitoring the health of local residents and tourists, and creating conditions for leisure and recreation. These negative effects could be neutralized through environmental, economic, and social measures if the accommodation capacities would be reduced from 23,000 to 6,000 beds.

\section{Discussion of Results and Lessons Learned}

The results of the previous studies elaborated upon the needs of two primary tourism destinations in PA with different phases of development - Djerdap National Park and Stara Planina Nature Park - indicating that the use of combined SEA and ESIA methodologies has directly influenced a more comprehensive consideration of problems in developing tourism-related activities in ecologically vulnerable areas (PA) and undeveloped rural areas. While standard SEA focuses solely on determining the effects of planning solutions on environmental quality, these case studies also indicate the necessity of determining 
the effects of tourism-related and complementary activities on the socio-economic development of local communities, the quality of life of people, and protection of natural and cultural heritage.

In a recent theoretical approach the assessment methodology in tourism destinations has been quite different, not only on a European but also on a regional level. While some of the authors [7, 15, 30] are more oriented toward the environmental impact of certain activities; on the other hand there are new theoretical aspects that are emphasizing social impact $[6,21,22]$ and very often economic impacts [29]. Also, there are differences between evaluations among the different methodologies. While some use pair-wise comparison [29], others use GIS-based multicriteria evaluation [21].

The particular methodology used within this research, on the other hand, provides a relatively comprehensive evaluation of the effects on all dimensions of sustainable tourism development, and suggests a corrective modification of the planned tourism, all for the purposes of achieving sustainable territorial development of tourism destinations in PA and its surroundings. Indicators defined for the needs of the ESIA application have been significantly extended compared to the standard goals and indicators prescribed for the application of SEA. Namely, they primarily refer to the incorporation of the effects of planning solutions on human health, the quality of life and socio-economic development of local communities, and natural and cultural heritage, but also on the possibility of strengthening the institutional competence of local administrations in the field of environmental protection and sustainable development of local communities.

By combining these two methodologies, the planning solutions with significant negative effects on the environment, heritage, and quality of life have been identified and eliminated. Furthermore, this also allowed the simultaneous evaluation of the different types of effects that have not been independently considered in the structure of the planning solutions, but evaluated synergistically.

Through the analysis of the area and activities using these two methods, the planning solutions whose realization would not cause significant conflicts in space have been clearly defined. In cases when conflicts were inevitable, ESIA has defined measures for diminishing or neutralizing the negative effects of planning solutions on the socio-economic development of local communities and on the quality of life of local residents.

ESIA has also provided recommendations for the reduction of accommodation capacities of Jabučko Ravnište Tourist Resort to a level that would not endanger the environment. These recommendations have been validated through the SPSPA Stara Planina.

Therefore, it is possible to comprehensively consider heterogeneous space of tourism destinations by establishing the system of measures for improving the quality of life and sustainability of tourism development as an integral part of sustainable territorial development of the area and local communities in PA.
In both cases the weakest part of the SEA/ESIA process has been related to the impacts on the landscape, as the landscape character assessment has not yet been carried out for the territory of Serbia. It is in the initial phase in Serbia - in preparation for the national action plan for the implementation of the European Landscape Convention in Serbia (started in 2014) [31], and the pilot project for the landscape character assessment in the Sumadija and Pomoravlje districts (started in 2015) [32].

The results of SEA with ESIA clearly indicate that the master plans have only been based on tourism profitmaking approach, without consideration of the sustainable development concept. By introducing ESIA instruments into solving the planning conflicts between the integral spatial plan and economy-oriented sector plan, certain tradeoffs were made, owing to which the sustainable territorial development of tourism in the most vulnerable area of the PA (Stara Planina Nature Park) has been retained. By doing so, the main purpose of the ESIA application has been accomplished.

Although SEA is not applied to master plans in the tourism sector for the time being, its application in spatial plans can contribute to achieving a certain balance between the sectoral and holistic approach to development and protection, with a view to achieving sustainable territorial development of tourism destinations and PAs. Through the combined use of complementary SEA and ESIA methodologies, an indirect control of sustainability of the planning solutions offered by the master plans for tourism destination/resort has been achieved, as well as an indirect coordination with spatial planning.

\section{Conclusions}

The coordination and integration of strategic planning is one of the priorities for achieving sustainable territorial development [33, 34], primarily with regard to spatial, environmental, and tourism planning. SEA/ESIA is an important control instrument for supporting the coordination and integration of strategic planning with a view to achieving sustainable territorial development. Although ESIA is not legally grounded in any EU directive, its application can contribute to better consideration of the specific problems of sustainable territorial development and provide support to planning options and solutions that will solve them in an ecologically and socially justifiable way.

The integration of combined SEA and ESIA methodologies in spatial planning for tourism destinations and urban planning for tourist resorts provides an adequate basis for the evaluation of different variants of planning solutions for developing and spatially organizing the tourism-related and other activities which have direct effects not only on environmental quality, but also on the protection of natural and cultural heritage, quality of life, and overall economic development. Combined SEA and ESIA practice in spatial and urban planning has indirectly made this assessment an important instrument for 
controlling and coordinating sectoral plans in tourism with sustainable territorial development of tourism destinations in PAs.

A precondition for SEA and ESIA to have a controlling and coordinating role is to initiate their application in tourism planning, used as the starting basis experiences related to SEA and ESIA implementation and integration into the spatial planning process, as well as to enable their adequate integration into the strategic planning process - from preparation to implementation, monitoring, and auditing of planning documentation.

\section{Acknowledgements}

This work resulted from research within project No. TR36036, "Sustainable development of the Danube area in Serbia," and No. III 47014, "The role and implementation of the National spatial plan and regional development in the renewal of strategic research, thinking and governance in Serbia" - both of which were financed by the Serbian Ministry of Education, Science, and Technological Development.

\section{References}

1. LEMOS C., FISCHER T., SOUZA M. Strategic environmental assessment in tourism planning - Extent of application and quality of documentation, Environmental Impact Assessment Review, 35, 1, 2012.

2. ADAMS N., ALDE J., HARRIS N. Regional Development and Spatial Planning in Enlarged European Union. Urban and Regional Planning and Development Series. Aschgate Publishing Ltd, 3, 2006.

3. UNITED NATIONS ECONOMIC COMMISSION FOR EUROPE (UNECE) Spatial Planning. Key Instrument for Development and Effective Governance with Spatial Reference to Countries in Transition. Geneve, 2008.

4. LEE K. Sustainable tourism destination: The importance of cleaner production. Journal of Cleaner Production, 9 (4), 313, 2001.

5. SCHIANETZ K., KAVANAGH L.,LOCKINGTON D. Concepts and Tools for Comprehensive Sustainability Assessments for Tourist destinations: A Comparative Review. Journal of Sustainable Tourism, 15 (4), 369, 2007.

6. FISCHER T., MATUZZI M., NOWACKI J. The consideration of health in strategic environmental assessment (SEA). Environment impact assessment review, 30, 200, 2010.

7. FISCHER T. The theory and practice of Strategic Environmental Assessment - Towards a More Systematic Approach. London: Earthscan, 2007.

8. ARTS J., MORRISON-SAUNDERS A. (Eds) Follow up in environmental Assesment, London: Earthscan, 2004.

9. EC DIRECTIVE. Directive 2001/42/EC of the European Parliament and the Council of $27^{\text {th }}$ June 2002, 2002, Retrieved from: http://www.environ.ie/en/Publications/Environment/ Miscellaneous/FileDownLoad,1805,en.pdf

10. NATIONAL ASSEMBLY OF THE REPUBLIC OF SERBIA. Law on Strategic Environmental Assessment, 2004, Retrieved from: http://www.ekoplan.gov.rs/en/2-Lawon-Strategic-Environmental-Impact-233-document.htm

11. NATIONAL ASSEMBLY OF THE REPUBLIC OF
SERBIA. Law on Tourism., 2009, Retrieved from: http:// www.tourism.merr.gov.rs/images/stories/materijal/Law on Tourism.pdf

12. MAKSIN M. Planning system for sustainable territorial development in Serbia. International Journal of Environment and Sustainable Development, 13 (3), 296, 2014.

13. NATIONAL ASSEMBLY OF THE REPUBLIC OF SERBIA. Law on Spatial Plan of the Republic of Serbia, 2010-2020, 2010, Retrieved from: http://www.rapp.gov.rs/ media/spatial_plan_rs.pdf

14. UNEP \& WTO. Making tourim more sustainable - A guide for policy makers. Paris, 2005.

15. DALAL-CLAYTON B., SADLER B. Strategic environmental assessment: a rapidly evolving approach. Environmental Planning Issues, 18, International institute for Environment and Development (IIED), 1999. Retrieved from http://pubs.iied.org/pdfs/7790IIED.pdf

16. STOJANOVIĆ B., MARIČIĆ T. Metodologija strateške procene uticaja prostornog plana rudarsko-energetskog kompleksa na životnu sredinu [The Methodology ofthe StrategicImpact Assessmentfor the Spatial Plan forMining andEnergy Complex] - in Serbian. Belgrade: Institute of Architecture and Urban \& Spatial Planning of Serbia, 2008.

17. KUO N., HSIAO T., YU Y. A Delphi-matrix approach to SEA and its application within the tourism sector in Taiwan, Environmental Impact Assessment Review, 25, 259, 2005.

18. THERIVEL R. Strategic environmental assessment in action. 2nd edition. London: Earthscan, 2010.

19. STOJANOVIĆ B., SPASIĆ N. A critical review of the implementationof the Law on Strategic ImpactAssessmentin spatial and urban planning [Kritički osvrt na primenu Zakona o strateškoj proceni uticaja na životnu sredinu u prostornom and urbanističkom planiranju] - in Serbian. Journal Izgradnja, 1-2, 5, 2006.

20. MAKSIN-MIĆIĆ M., MILIJIĆ S., NENKOVIĆ-RIZNIĆ M. Spatial and environmental planning of sustainable regional development in Serbia, International journal Spatium, 21, 39, 2009.

21. NENKOVIĆ-RIZNIĆ M., MILIJIĆ S., KRUNIĆ N. Strategic flood impact assessment in the spatial planning of catchment areas (case study Tamnava Basin). Proc. International Scientific Conference on Forestry. Belgrade: Faculty of Forestry, University of Belgrade, 776, 2010.

22. ALONSO J., ALCANTAR-CARRIO J.,CABRERA L.Tourist Resorts and their Impact on Beach Erosion at Sotavento Beaches, Fuerteventura, Spain. Journal of Coastal Research, Special Issue, 36, 1, 2002.

23. INSTITUTE OF ARCHITECTURE AND URBAN \& SPATIAL PLANNING OF SERBIA. The Spatial Plan for the Special-Purpose Area of „Djerdap“ National Park (Prostorni plan područja posebne namene Nacionalnog parka „Djerdap“) - in Serbian, 2011.

24. INSTITUTE OF ARCHITECTURE AND URBAN \& SPATIAL PLANNING OF SERBIA. The Report on the SEA for the Spatial Plan for the Special Purpose Area of „Djerdap“ National park (Izveštaj o Strateškoj proceni uticaja Prostornog plana područja posebne namene Nacionalnog parka „Djerdap“ na životnu sredinu) - in Serbian, 2011.

25. INSTITUTE OF ARCHITECTURE AND URBAN \& SPATIAL PLANNING OF SERBIA. The Report on the SEA for the Spatial Plan for the Special-Purpose Area of Tourist Region and Nature Park „Stara planina“ (Izveštaj o Strateškoj proceni uticaja Prostornog plana područja posebne namene parka prirode „Stara planina“ na životnu sredinu) - in Serbian, 2009.

26. GOVERMENT OF THE REPUBLIC OF SERBIA. Spatial 
Plan of the Nature Park and Tourism Area of Stara planina - in Serbian, 2008, Retrieved from: http://195.250.98.80/ rapp_mape/113/Plan_Stara-pl.pdf

27. MINISTRY OF ECONOMY OF THE REPUBLIC OF SERBIA Master plan of Lower Danube Tourism Destination [Master plan turističke destinacije Donje Podunavlje] - in Serbian. 2007, Retrieved from: http://www.turizam.privreda. gov.rs/images/stories/SVI MASTER PLANOVI/Donje Podunavlje/Master plan Donje Podunavlje.pdf

28. ECOSIGN - MOUNTAIN RESORT PLANNERS LTD. Stara Planina Resort Area Master Plan, 2007.

29. ŠAUER P., KREUZ, J., LISA A. Assessing Efforts to Mitigate Particulate Matter Air Pollution in the MoravianSilesian Region, Polish Journal of Environmental Studies, 23 (6), 2233, 2014.

30. FISCHER, T. Comparative analysis of environmental and socio-economic impacts in SEA for transport related policies, plans, and programs. Environment impact assessment review, 19, 275, 1999.
31. INSTITUTE OF ARCHITECTURE AND URBAN \& SPATIAL PLANNING OF SERBIA. Draft of Action plan for the implementation of the European Landscape Convention in Serbia [Nacrt Akcionog plana za implementaciju Evropske konvencije o predelu u Srbiji] - in Serbian, 2014.

32. REGIONAL DEVELOPMENT AGENCY FOR SUMADIJA AND POMORAVLJE. Improvement of the Sumadija and Pomoravlje capacity to implement the European Landscape Convention. 2015.

33. GUNN C. Tourism planning: basics, concepts, cases. New York; London: Routledge, 2002.

34. DALAL-CLAYTON B., SADLER B. Strategic Environmental Assessment: A Sourcebook and Reference Guide to International Experience - a Sourcebook and reference Guide to International experience, Abingdon: Routledge, 2005. 